\title{
The Effect of Capital Readiness and E-Commerce Utilization on the Competitiveness of Micro, Small, and Medium Enterprises Woven, Palembang
}

\author{
Sulaiman ${ }^{1}$, Bramntyo Muhamad Pangestu ${ }^{2,}$, Bainil Yulina $^{3}$, Siska Aprianti ${ }^{4}$ \\ ${ }^{1-4}$ Accounting Department, State Polytechnic of Sriwijaya, Indonesia \\ "Corresponding author Email: bramantyomuhamadpangestu@gmail.com
}

\begin{abstract}
This research is about the relationship and the effect of capital readiness, E-commerce Utilization on the competitiveness of tajung weaving small businesses in Palembang. The analysis technique used in this study is multiple linear regression analysis using primary data obtained directly from the studied sources, 90 people of weaving weavers in Palembang Kentang Region. The results stated Simultaneously Capital Readiness (X1), Ecommerce Utilization (X2), significant positive effect and contributed to the competitiveness (Y1) of SMEs in Tajung Weaving in the Tuan Kentang area of Palembang by $66.7 \%$ percent. Capital readiness has a positive and significant effect on the competitiveness of SMEs in tajung woven fabric in Palembang city and this is consistent with the initial hypothesis of the study where capital readiness has a positive relationship on competitiveness. Regression coefficient which shows this positive relationship means the greater the value of capital readiness, the greater the competitiveness obtained. Partially, the E-commerce Utilization variable has a positive and significant influence on the competitiveness of tajung weaving businesses. This is in line with the hypothesis at the beginning of the study that E-commerce Utilization affects business competitiveness, meaning that the higher the E-commerce Utilization of a business, the more competitiveness is achieved.
\end{abstract}

Keywords: capital readiness, technology utilization, competitiveness

\section{INTRODUCTION}

Competitiveness is important in running a business/business. The existence of competitiveness of companies and even MSMEs will be able to increase product innovation and others by considering various possibilities that occur. Competitiveness has a relative characteristic because to determine it needs comparison, it means that competitiveness depends on who its competitors are, it could be that at one time a company has high competitiveness but at other times when competitors change to become more competent, competitiveness will decrease against its competitors. The existence of competition will bring competitiveness that is positive for progress. That way, someone will improve the quality of themselves from various sides and try to overcome the weaknesses that exist to increase competitiveness. The same thing happens in MSMEs, that MSME competitiveness has a quite dominant role in the area. According to [1], explaining competitiveness is a general concept used in economics that usually refers to a commitment to market competition meaning business actors have the ability in competing to maintain the products produced in the market. . In other words, competitiveness can be interpreted as the ability of something or someone to grow and develop well among similar entities in the same environment.
One factor that dominates small business activities in Palembang is the handicraft sector, specifically songket and weaving. There are many songket and weaving craftsmen scattered in the city of Palembang.

According to a survey that has been done to MSME woven fabrics in the area of potato host, some of the micro, small and medium businesses have very tight competition in seizing the market. This is evidenced by the competition in terms of price, product innovation, and services provided to attract consumers. Today, many of the MSMEs are more concerned with low prices without taking into account the quality of the product or service itself. So that MSMEs only get short-term benefits. Various innovations should always be done by MSMEs to progress their business. MSMEs who cannot adjust to the market through price and innovation will gradually experience a turnover. The tight competition in obtaining the turnover will be a serious matter for SMEs. If the decline in turnover occurs continuously, MSMEs inevitably have to increase capital to facilitate the operation of the business. But many of MSMEs do not have sufficient capital (minimal capital). According to Annisa Diana Haq in her research entitled the analysis of the factors that influence the competitiveness of SMEs in Bantul Regency, namely, in terms of human resources, product excellence, innovation, and marketing with information technology.

The existence of competition certainly makes micro, small and medium enterprises must prepare capital which will 
be an important role in correcting the weaknesses that exist in the company. This capital is not only in the form of the amount of money needed but also the readiness of businesses in dealing with fluctuating market conditions and conditions called capital expertise. With capital, all micro, small and medium businesses can carry out production activities and other business activities. , micro, small and medium enterprises can still run but can only carry out very limited activities. Business actors also cannot seize the market well if there is minimal capital. From this statement it can be concluded that the readiness of capital will affect production activities and other business activities so as to make micro, small and medium enterprises indirectly unable to seize the market with the goods and services offered. Gradually, MSMEs will experience a turnover.

The lack of capital gives its own concern that which is always a problem related to increasing competitiveness is capital. Some MSMEs state that they prefer to develop their own capital rather than having to get it from a third party. This is because the requirements and procedures for obtaining capital are quite long and also MSMEs only get a limited amount. Meanwhile, MSMEs can only depend on the proceeds of sales of products that are generated to get money back and turn it into the next production activity. When a decline in sales results, MSMEs must find other alternatives to run a business so that it requires good capital management to run business activities.

Nowadays, online business is growing rapidly among the people. People unconsciously use it in the process of meeting their needs. Demand in meeting diverse needs is utilized by micro, small and medium business entrepreneurs to provide online services. Businesses are competing to attract consumers without having to look around and pay for marketing services in marketing their products. They only need a few internet networks to connect with some consumers who need the products we produce. The use of the internet is believed to increase sales turnover and ease in transactions.

Utilizing E-commerce or what is often called the internet makes micro, small and medium businesses in the Tuan Potato region work hard. According to [2] E-commerce is the process of buying, selling, sending, or exchanging products and services and information through computer networks, which are mostly the internet. Business people object to online business but gradually the perpetrators must dare to take risks to go directly into cyberspace (online). The courage to take advantage of E-commerce or the internet has not been felt by all SME woven fabrics in Palembang.

In addition, researchers by [3] said there was an increase in competitiveness with network technology or we often call it the internet. This study states that every small business needs the internet to develop competitiveness that will be carried out.

Based on the background above, the problems to be examined in this study can be seen as follows:

1. How does capital readiness influence the competitiveness of Woven Fabric MSMEs in the Tuan Kentang Region of Palembang?
2. How is the influence of the use of E-commerce on the competitiveness of MSME Woven fabrics in the Tuan Kentang Region of Palembang?

3. How does the effect of capital readiness and the use of E-commerce together to increase the competitiveness of SMEs Woven fabrics in the Tuan Kentang Region of Palembang?

This study aims to determine the effect of capital readiness, the use of E-commerce on the competitiveness of micro, small and medium enterprises Woven fabrics in the Tuan Kentang Area of Palembang.

\section{LITERATURE REVIEW}

Companies that are able to produce goods and services of good quality will gain competitiveness. With competitiveness means the company has an advantage. The company's excellence will make it survive in the competitive market in the long run. Competitiveness relates to how effective an organization is in competitive markets.

Competitiveness is a concept commonly used in economics, usually referring to commitment to market competition in the case of companies and success in international competition in the case of countries [1]. From this definition it can be concluded that competitiveness is the ability of something or a person to grow and develop well among similar entities in the same environment to win the market.

In the business world, capital readiness is something that must be achieved by management to carry out its business. Improved business continuity will have an impact on the turnover obtained and the quality of the competitiveness of companies and micro, small and medium businesses. With a turnover, the company will be able to finance all subsequent business operations.

From the definition of readiness and capital that have been put forward by several experts, it can be concluded that the understanding of capital readiness is an ability in certain circumstances to get better business results so that it is able to carry out further production activities. According to [4] states that there are several types of capital that can be used in business activities. Basically, the capital needs to do business itself consists of investment capital and working capital. Investment capital is used for the long term and can be used repeatedly. Its use is for the purchase of fixed assets such as land, buildings or buildings, machinery, equipment, vehicles and so on. Meanwhile, working capital is used to finance the company's operations while the company is operating. Short-term working capital used for the purposes of purchasing raw materials, paying employee salaries, and maintenance costs and other costs.

Indicators of capital readiness according to the SME Entrepreneurship Study Center, LPPM Indonusa Esa Unggul, states there are 4, including confidence in the workforce, clear division of tasks, management capabilities and business planning. 
Many cases from micro, small and medium businesses that override the benefits of using e-commerce itself. Business people assume that the use of e-commerce only wastes time, energy and costs to make a company grow without considering the positive benefits that will be obtained in the future to promote its products and increase sales turnover. Utilization of E-commerce or we often refer to online buying and selling for small companies namely MSMEs will provide flexibility in production, can provide faster shipping information to customers, send and receive offers quickly and economically, and can support transactions quickly without paper This is what will encourage micro, small and medium businesses to improve competitiveness. According to the above review, the use of E-commerce is a way, process and act of utilizing computer / internet networks to conduct transactions of buying and selling products or services and services provided whether it's marketing, development, payment, or delivery with the aim of increasing revenue.

According to [5] the development of information technology has penetrated into all walks of life, including the business world. In various businesses in Indonesia, both MSMEs and Large Enterprises, the use of computers in the field of sales in recent years is growing rapidly. With the internet, the sales process can be done anytime and anywhere without being bound by time and space [6] and [7]

\section{RESEARCH METHODS}

In this study, researchers examined the effect of capital readiness and e-commerce on the competitiveness of micro, small and medium-sized woven fabric in the Palembang Potato Area. Capital readiness $\left(\mathrm{X}_{1}\right)$ and Ecommerce $\left(\mathrm{X}_{2}\right)$ as independent variables while MSME competitiveness $\left(\mathrm{Y}_{1}\right)$ as the dependent variable. To be able to understand it can be seen in the Figure 1:

Research Hypothesis

Based on the literature review and thinking framework above, the researcher proposes the following hypotheses.

H1 : Capital Readiness has a positive and significant effect on the competitiveness of UMKM woven fabrics in the Tuan Potato Region of Palembang.

$\mathrm{H} 2$ : Utilization of E-commerce has a positive and significant effect on the competitiveness of MSME woven fabrics in the Tuan Potato Region of Palembang.

H3: Capital Readiness and E-commerce Utilization have a positive and significant influence on the competitiveness of MSMEs woven fabrics in the Tuan Kentang Region of Palembang.

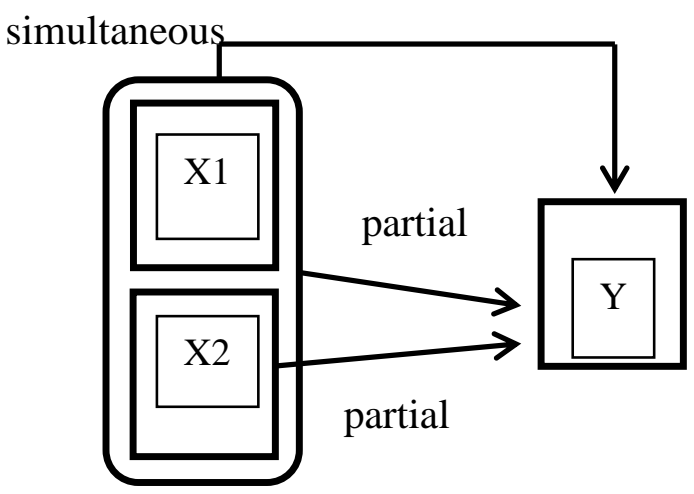

Figure 1 Research paradigm

Information:

X1 Capital Readiness

X2 E-commerce Utilization

Y MSMEs Competitiveness

\section{RESULTS AND DISCUSSION}

Based on the SPSS results obtained indicate that adjusted square values of 0.667 (66.7\%), with $\mathrm{R}$ square of 0.744 (74.4\%). It can be concluded that $66.7 \%$ of the MSME competitiveness variable $(\mathrm{Y})$ is influenced by the variable Capital Readiness (X1), E-commerce Utilization (X2) while the remaining $34.3 \%$ is explained by other variables not examined in this research.

Hypothesis testing

F-Statistic test

Based on Table 1, a significance value of 0.003 is obtained with a Fcount of 9,679 > 2.85 because $F$ arithmetic $>\mathrm{F}$ of the table and a significance value of $0.003<0.05$, so it can be concluded that the linear regression model estimated is appropriate to be used to explain the effect of capital readiness, E Utilization commerce towards Competitiveness of Tajung Small Weaving Business.

Table 1 F-statistical Test Results

\begin{tabular}{|c|c|c|c|c|c|c|}
\hline \multicolumn{7}{|c|}{ ANOVA $^{a}$} \\
\hline & del & Sum of Squares & df & Mean Square & $\mathrm{F}$ & Sig. \\
\hline \multirow{3}{*}{1} & Regression & 7.211 & 3 & 2.404 & 9.679 & $.003^{b}$ \\
\hline & Residual & 2.483 & 10 & .248 & & \\
\hline & Total & 9.695 & 13 & & & \\
\hline
\end{tabular}

T-Statistical Testing

Based on table 2, the significance value X1 of capital readiness is obtained with a tcount of 3,399>2,0226. From the significance value obtained shows $0.007<0.05$. then it can be concluded that the first hypothesis is accepted, which means that capital readiness significantly influences the competitiveness of Tajung Small Weaving Business in the Tuan Kentang Area of Palembang.

Based on table 5.7 obtained the significance value of $\mathrm{X} 2 \mathrm{E}$ commerce Utilization with tcount of $-3.578>2.0226$. The 
significance value obtained shows $0.005<0.05$. then it can be concluded that the second hypothesis is accepted, which means that E-commerce Utilization has a significant effect on the Competitiveness of Tajung Small Weaving Business in the Tuan Kentang Area of Palembang.

Table 2 T-Statistical Test Results (parsial)

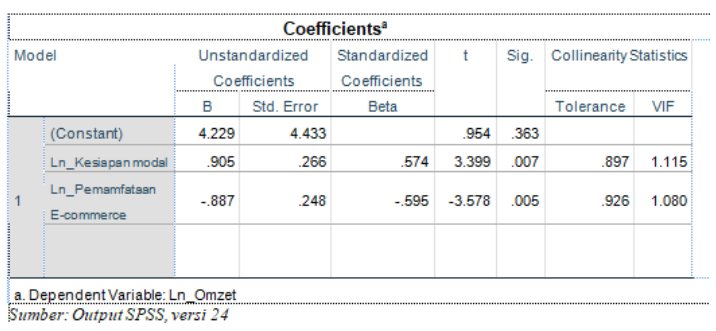

Capital Readiness has a positive and significant effect on the competitiveness of Micro, Small and Medium Enterprises in the Tuan Potato Region. This can be seen by comparing $r$ tables with $r$ counts. $r$ count on the variable capital readiness of 0.518 while $r$ table 0.134 , means the value of $r$ count is bigger than the value of $r$ table.

According to the theory of capital readiness and competitiveness by Porter (2010) explains the existence of competitiveness of Small and Medium Enterprises is measured by using an index formed based on the four dimensions of the port in which there are sources of capital. This capital can help in increasing production and sales turnover so that the market can respond well to the results of our production and business services. Thus, to form a strong competitiveness, capital readiness is needed to continue the business continuity.

The results of the above research are in line with previous studies conducted by Hendra Susanto (2015) entitled "Analysis of Factors Affecting the Perception of Batik Businesses in Yogyakarta City in Facing the Asean Economic Community 2015". The results of the study mentioned that the capital factor is the main factor related to production as well as venture capital in increasing competitiveness in the AEC free market. Thus it means that each capital readiness has a positive and significant influence on competitiveness. The higher competition there is with the emergence of several new businesses in the Tuan Potato Region, the higher the capital readiness that must be obtained to get a better sales turnover. Vice versa. So, to improve the competitiveness of MSMEs, it is necessary to pay attention to the readiness of capital in micro, small and medium businesses to run a business and get a sales turnover exceeding the specified target.

The results showed a correlation coefficient $\left(\mathrm{r}_{\mathrm{x} 2 \mathrm{y}}\right)$ of 0.442 , which means there was a positive relationship between the use of e-commerce to the competitiveness of MSMEs. The $t$ test carried out showed the $t$ value of 7.202 while the $t$ table with a significance level of $5 \%$ of 1.97 so that the effect of E-commerce Utilization on MSME Competitiveness was significant. For the coefficient of determination $\left(\mathrm{r}_{\mathrm{x} 2 \mathrm{y}}^{2}\right)$ of 0.195 or $19.5 \%$ means the influence of the E-commerce Utilization variable of $19.5 \%$ on MSME competitiveness and for the rest is influenced by factors other than e-commerce utilization.

The results of the research concluded that the hypothesis which reads "Utilization of E-commerce has a positive and significant effect on the competitiveness of Micro, Small and Medium Enterprises (MSMEs) in the Tuan Kentang Region." This can be seen by comparing $r$ arithmetic with $r$ tables. The $\mathrm{R}$ count on the E-commerce Utilization variable is 0.442 while the $r$ table is 0.134 , meaning the $r$ count value is bigger than the $r$ table value. According to the theory of the use of e-commerce and competitiveness by Turban and Humdiana (2006) that the use of ecommerce can help some small businesses to compete with large companies and also expand their reach to all regions so as to improve supply management in facilitating business operations. Thus, the existence of business actors who take advantage of technological developments such as e-commerce can provide added value in competing with other business actors.

This study is in line with previous research conducted by Pebruati, Handayani, and Zahroh (2012) entitled "The Effect of Information Technology Applications in Increasing Company Competitiveness (Study on MSMEs in Malang City). The results of statistical calculations for IT utilization variables call the value of inner weight of 0.697 with a significance of 0.000 means that this significance value indicates the variable is significant.

The results of this study indicate that there is a positive and significant effect on capital readiness and e-commerce utilization in the Tuan Potato Region. The results of the analysis using multiple regression analysis obtained the correlation coefficient $\mathrm{R}_{\mathrm{y}(\mathrm{x} 1, \mathrm{x} 2)}$ of 0.556 means that there is a positive relationship between the Capital Increase and Ecommerce Utilization of the Competitiveness of Micro, Small and Medium Enterprises. Furthermore, the F test was carried out and the $F_{\text {count }}$ value was 49,378 and the $\mathrm{F}_{\text {table }}$ was 3.04 at the 5\% significance level with $d f 214$. After seeing the $\mathrm{F}$ test results, it was concluded that the $F_{\text {count }}$ was bigger than $F_{\text {table }}(47,587>3.04)$ meaning that there was a significant influence . For the coefficient of determination the result is 0.317 or $31.7 \%$, which means the variable Capital Readiness and E-commerce Utilization has an influence of $31.7 \%$ and the remaining $68.3 \%$ is influenced by other factors. The results of this study state that the hypothesis that reads "Capital Readiness and E-commerce Utilization has a positive and significant effect on the Competitiveness of Micro, Small and Medium Enterprises in the Tuan Kentang Region is accepted. This can be seen by comparing $F_{\text {count }}$ with $F_{\text {table }}$. $F_{\text {count }}$ is 49,378 while $F_{\text {table }}$ is 3.04 . In accordance with the theory put forward by Tambunan (2011) states that the determinants of competitiveness include the availability of capital and the availability of technology. In addition, Porter (2010) also mentioned that there are several dimensions that will affect the activities and competitiveness of MSMEs, including the dimensions of the factor conditions in which there are sources of science and technology as well as capital resources. 
With the capital readiness and the existence of technology that supports micro, small and medium businesses, it will provide added value in competing in markets that have a variety of products and services offered by other micro, small and medium businesses. This research is in line with [6] he results of this study state that capital is the main factor related to production and business capital in increasing competitiveness in the 2015 MEA free market. In addition, research according to [7] that IT acceptance has a significant effect on company competitiveness. This means that capital readiness and e-commerce utilization are very important in developing MSME competitiveness. Capital readiness and e-commerce utilization have a contribution of $31.7 \%$ and this means that there are still other factors or influences that affect MSMEs competitiveness in Sleman Regency Yogyakarta. In accordance with the theory of capital readiness, ecommerce utilization, and competitiveness that some of the factors above can be used to determine competitiveness.

\section{CONCLUSION}

Simultaneously, Capital Readiness, E-commerce Utilization, has a significant positive effect and contributes to the Competitiveness of Tajung Weaving MSMEs in the Tuan Kentang area of Palembang by $66.7 \%$ percent. Capital readiness has a positive and significant effect on the competitiveness of MSMEs in tajung woven fabric in Palembang and this is in accordance with the initial hypothesis of the study where capital readiness has a positive relationship on competitiveness. Partially, the E-commerce Utilization variable has a positive and significant effect on power Tajung weaving business competitiveness. This is in accordance with the hypothesis at the beginning of the research.

\section{REFERENCES}

[1] Anwar, Hasan. "Analisis Pengaruh Aset, Keuntungan, Lama Usaha, Presepsi Tingkat Bunga, Jenis Kelamin, Pendidikan, dan Usia, Terhadap Keputusan UMKM Mengambil Kredit Perbankan" (Studi Kasus: Kabupaten Kudus). Skripsi Universitas Diponegoro, 2013.

[2] Jihad, Noer Muhammad. "Analisis Pengaruh Suku Bunga dan Pemberian Kredit terhadap Unit Tenaga Kerja dan Omzet UMKM". Universitas Brawijaya, 2014.

[3] Malik, Rachmawati. "Analisis Pengaruh Kredit, Aset, dan Jumlah Pegawai terhadap Pendapatan Usaha Kecil Menengah (UKM) Penerima Kredit Bank Perkreditan Rakyat”. Jurnal Ilmu Administrasi Vol. 5 No. 1 Tahun 2007. Fakultas
Ekonomi Universitas Riau, 2012.

[4] Sugiyono. "Statistika Untuk Penelitian". Alfabeta. Bandung, 2012.

[5] Sugiyono. "Metode Penelitian Kuantitatif dan Kualitatif R\&D”. Alfabeta. Bandung, 2011.

[6] Aprianto. “Analisis Faktor yang Mempengaruhi Persepsi Pelaku Usaha Batik di Kota Yogyakarta Dalam Menghadapi Masyarakat Ekonomi ASEAN (MEA) 2015”. Yogyakarta, 2015.

[7] Pebruati. "Pengaruh Aplikasi Teknologi Informasi Dalam Peningkatan Daya Saing Perusahaan". Malang, 2011. 